\section{Lead Poisoning Mortality in Wild Passeriformes and its Detection in Free-Range Chicken Eggs in Southern Minas Gerais, Brazil}

\section{Author(s)}

Martins NRS

Marques MVR'

Vilela DAR ${ }^{2}$

Resende JS 1

Carvalhaes $A G^{1}$

Andrade $\mathrm{EAG}^{1}$

Barrios $\mathrm{PR}^{3}$

Setor de Doenças das Aves

Departamento de Medicina Veterinária Preventiva. Escola de Veterinária da UFMG.

2 Analista Ambiental, CETAS

Instituto Brasileiro de Meio Ambiente e Renováveis, IBAMA.

3 Departamento de Medicina Veterinária/ DMV. Universidade Federal de Lavras.

\section{Mail Address}

Nelson R. S. Martins

Av. Antônio Carlos 6.627

Caixa Postal 567

30.123-970. Belo Horizonte, MG, Brazil.

Telephone: (55 31) 3409-2093

Fax: $\quad$ (55 31) 3409-2080

E-mail:nrsmart@gmail.com

\section{Keywords}

Battery recycling, car, free-range chicken, lead, passerine.

\section{Acknowledgements}

The authors are indebted to $\mathrm{Dr}$. Jorge Barquete, Lab. Hidrocepe, Belo Horizonte, Brazil, for lead analyses and to CNPq, FAPEMIG and FEP/MVZ for financial support.

\section{ABSTRACT}

The mortality of passerines native of Southern Minas Gerais, Brazil, in August 2006 and the examination of sentinel free-range chicken eggs in August 2007 in an area surrounding a car battery lead smelter plant is described. The high levels of lead, as detected in the passerines (4.80$12.74 \mathrm{mg} / \mathrm{kg}$ ) at the onset of mortality and at the follow-up sampling of the free-range chicken eggs $(25.02-35.21 \mathrm{mg} / \mathrm{kg}$ in shells, $0.41-1.36$ $\mathrm{mg} / \mathrm{kg}$ in yolks and $0.40-0.75 \mathrm{mg} / \mathrm{kg}$ in the albumins), used as environmental sentinels, indicated the continuing lead pollution.

\section{INTRODUCTION}

Lead is a highly toxic and the main heavy metal causing intoxication of birds. The most common sources of lead are fishing weights, important for aquatic birds as lead shots, and for caged birds, lead-containing paint (Brown \& Julian, 2003). Avian poisoning may be sub-lethal or lethal and affect birds and other animals living near sources of lead (Pain et al., 1995). The recycling of lead from car batteries has become an important issue as far as environmental pollution is concerned. The recycling of car batteries is essential for proper disposal of such leadcontaining material. However, lead processing requires adequate chemical safety procedures to prevent the exposure of humans and the environment (Levine et al., 1976). This paper reports an episode of acute lead poisoning causing mortality in passerines of the Brazilian fauna in August 2006, and describes a follow-up investigation in August 2007 in the same area, on the contamination of free-range chickens producing subsistence consumable eggs, in an area surrounding a lead smelting plant of Southern Minas Gerais, Brazil, aiming to alert for the environmental, animal and human risk.

\section{MATERIALS AND METHODS}

Passeriformes of the species "Blue Dacnis" (Dacnis c. cayana), one male and 2 females; "Chestnut-vented Conebill" (Conirostrum s. speciosum), one female; "Rufous-browed Peppershrike" (Cyclarhis gujanensis), one male; and "Sayaca Tanager" (Thraupis sayaca), 2 males, were found dead in an area surrounding a lead recycling plant and sent by the Police Department to the Avian Diseases Laboratory at the Veterinary College (Universidade Federal de Minas Gerais, Brazil) for diagnosis in August 2006. Eggs $(n=33)$ of eleven flocks of free-range chickens of the neighboring area were sampled at 11 sites as environmental sentinels one year later (August 2007). The smelter plant is pointed by the white arrow below site 3 on the map (Figure 1). Lead atomic absorption spectrophotometer analyses were performed in liver, lung, heart and intestinal sampled of passerines pooled by location, in 
Martins NRS, Marques MVR, Vilela DAR, Resende JS, Carvalhaes AG, Andrade EAG, Barrios PR

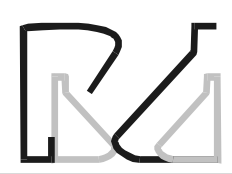

free-range chicken egg shells $(n=11)$, yolks $(n=11)$ or albumen $(n=11)$ (Lab. Hidrocepe, Belo Horizonte, Brazil).

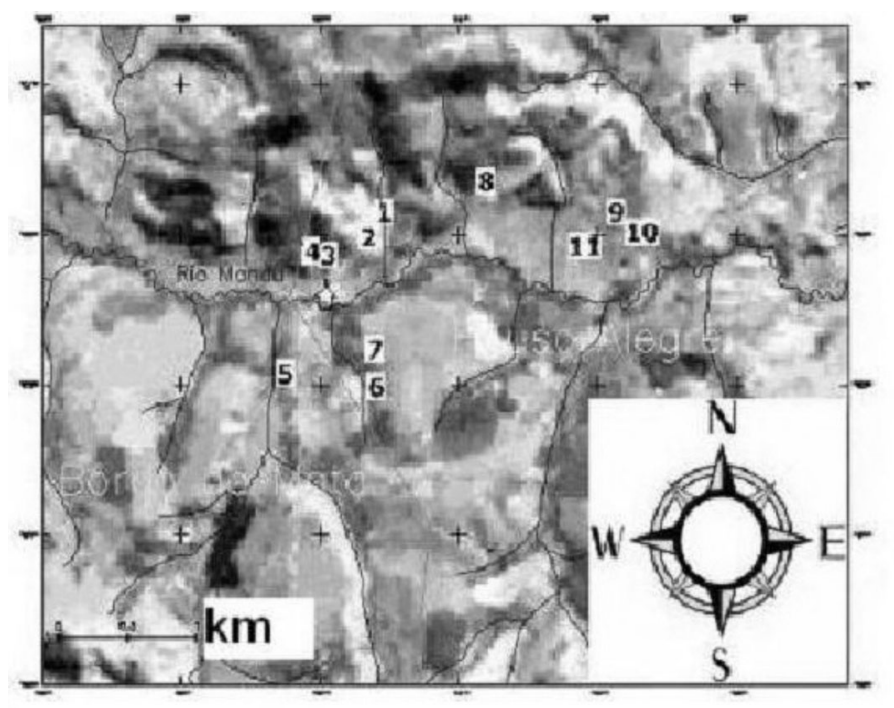

Figure 1 - Free-range egg sampling area.

The geographical location of the eleven collection sites are shown. The smelter plant is located as indicated by the arrow positioned below site number 3 . The geographical coordinates and values in shell, yolk and albumin, respectively, in $\mathrm{mg} / \mathrm{kg}$, at each location are as follows

site 1: $S 22^{\circ} 16^{\prime} 23.3^{\prime \prime} W 46^{\circ} 03^{\prime} 26,4^{\prime \prime} / 843 \mathrm{~m}, 29.55,1.36$ and 0.48 ; site 2: $\mathrm{S}^{\circ} 2^{\circ} 16^{\prime} 28.9^{\prime \prime} \mathrm{W} 46^{\circ} 03^{\prime} 30,4^{\prime \prime} / 870 \mathrm{~m}, 27.12,1.34$ and 0.49 ; site 3: S22 $12^{\circ} 32.8^{\prime \prime} \mathrm{W} 46^{\circ} 03^{\prime} 40,4^{\prime \prime} / 852 \mathrm{~m}, 30.58,1.25$ and 0.66 ; site 4: $\mathrm{S} 22^{\circ} 16^{\prime} 31.9^{\prime \prime} \mathrm{W} 46^{\circ} 03^{\prime} 44,6^{\prime \prime} / 842 \mathrm{~m}, 25.02,0.97$ and 0.62 ; site 5: $522^{\circ} 16^{\prime} 58.2^{\prime \prime} \mathrm{W}^{\circ} 6^{\circ} 03^{\prime} 51,4^{\prime \prime} / 844 \mathrm{~m}, 28.40,0.90$ and 0.49 ; site 6: $\mathrm{S} 22^{\circ} 17^{\prime} 01.5^{\prime \prime} \mathrm{W} 46^{\circ} 03^{\prime} 28,7^{\prime \prime} / 848 \mathrm{~m}, 28.12,0.41$ and 0.42 ; site 7: $S 22^{\circ} 16^{\prime} 53,2^{\prime \prime} \mathrm{W} 46^{\circ} 03^{\prime} 29,3^{\prime \prime} / 847 \mathrm{~m}, 35.21,0.72$ and 0.67 ; site 8: $S 22^{\circ} 16^{\prime} 17,1^{\prime \prime} \mathrm{W} 46^{\circ} 03^{\prime} 00,9^{\prime \prime} / 838 \mathrm{~m}, 33.07,0.82$ and 0.40 ; site 9: $S 22^{\circ} 16^{\prime} 23,9^{\prime \prime} \mathrm{W} 46^{\circ} 02^{\prime} 28,2^{\prime \prime} / 843 \mathrm{~m}, 27.69,0.81$ and 0.67 ; site 10: $S 22^{\circ} 16^{\prime} 28.3^{\prime \prime} \mathrm{W} 46^{\circ} 02^{\prime} 21,6^{\prime \prime} / 862 \mathrm{~m}, 29.73,0.97$ and 0.64 ; site 11: S22 $12^{\prime} 31.4^{\prime \prime} \mathrm{W} 46^{\circ} 02^{\prime} 36,0^{\prime \prime} / 862 \mathrm{~m}, 34.14,1.03$ and 0.75 . Note: Values for each location are latitude South, longitude West, altitude, and lead concentrations $(\mathrm{mg} / \mathrm{kg}$ ) found in the shell, yolk and albumen, respectively, of free-range chicken eggs.

\section{RESULTS AND DISCUSSION}

In the laboratory, passerine species were identified (Figure 2) and the acute or superacute aspect of the disease of the otherwise apparently healthy birds was noted during necropsy. Whitish material deposits (Figure 3) were observed in the oral cavity obstructing the palatine cleft, which was swollen, indicating the ingestion or action of an irritating substance on the palate, in the intestinal lumen, as well as on the liver surface (Figure 3), and in the liver parenchyma. The whitish deposits were also visible in the lungs, indicating inhalation, in the kidneys parenchyma, possibly as a result of circulating levels in blood, and also accumulated in the thoraco-abdominal cavity (Figure
Lead Poisoning Mortality in Wild Passeriformes and its Detection in Free-Range Chicken Eggs in Southern Minas Gerais, Brazil
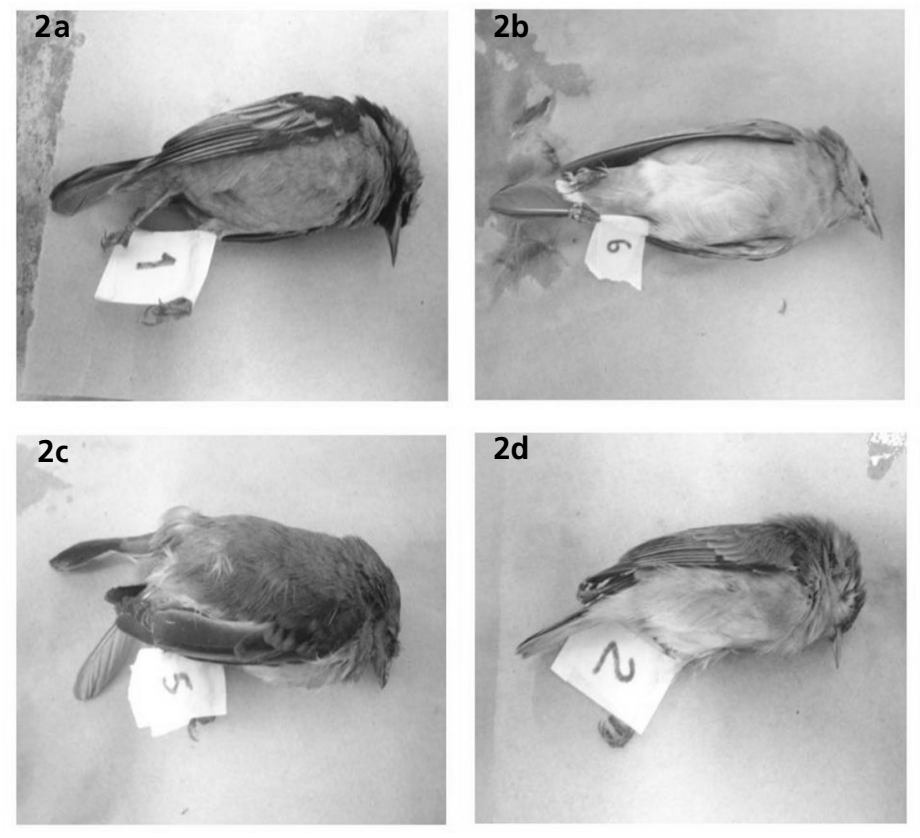

Figure 2 - Passerine species examined.

The Passeriformes of species "Blue Dacnis" (Fig. 2a, Dacnis c. cayana), one male and 2 females, "Sayaca Tanager" (Fig. 2b, Thraupis sayaca), 2 males, "Chestnut-vented Conebill" (Fig. 2c, Conirostrum s. speciosum), one female and "Rufous-browed Peppershrike" (Fig. $2 \mathrm{~d}$, Cyclarhis gujanensis), one male, were found dead in an area surrounding a lead recycling plant.
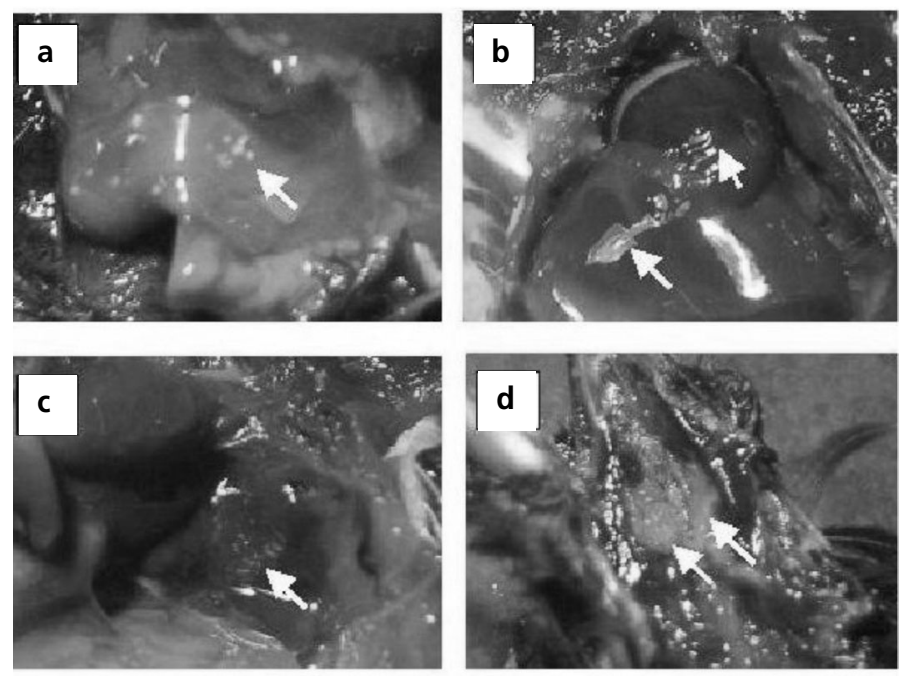

Figure 3 - Typical lesions observed at the necropsy of passerines.

a. Dacnis c cayana. Intestinal insoluble whitish material (arrow). b. Thraupis sayaca. Insoluble whitish material deposit on the liver surface (long arrow). Note cardiac distension. (short arrow, darker area). c. Cyclarhis gujanensis. Pulmonary whitish deposits (arrow). d. Cyclarhis gujanensis. palatine cleft mucosal lesion (arrows).

3). The concentrations of lead in the passerines ranged between 4.80 and $12.74 \mathrm{mg} / \mathrm{kg}(4.80-12.77 \mathrm{mg} / \mathrm{kg})$ in the pooled visceral and tubular organs samples of each individual (Table 1). Free-range chickens eggs 


\begin{tabular}{lcl}
\hline $\begin{array}{l}\text { Table } \mathbf{1} \text { - Lead concentrations in passerine species and post } \\
\text { Scientific name }\end{array}$ & $\begin{array}{c}\text { mortem examination details. } \\
\text { Lesions at necropsy }\end{array}$ \\
Conirostrum s. speciosum & 7.38 & Whitish deposits $\sim 1 \mathrm{~mm} \varnothing$ on the surface of the enlarged liver; swollen cloaca \\
Cyclarhis gujanensis & 7.48 & Palatine cleft swollen and obstructed; whitish deposits $(\sim 1 \mathrm{~mm} \varnothing)$ in the lungs \\
Dacnis c. cayana & 7.98 & Whitish deposits on the skin $(<2 \mathrm{~mm} \varnothing)$ \\
Dacnis c. cayana & 4.80 & Whitish deposits in the intestinal lumen $(<2 \mathrm{~mm} \varnothing)$ \\
Dacnis c. cayana & 6.79 & Whitish round $($ approx. $1 \mathrm{~mm} \varnothing)$ deposits on the liver surface \\
Thraupis sayaca & 11.55 & Intraperitoneal fine granular deposits $(\sim 1 \mathrm{~mm} \varnothing) ;$ cardiac distension \\
Thraupis sayaca & 12.74 & Intraperitoneal fine granular deposits $(<2 \mathrm{~mm} \varnothing) ;$ cardiac distension \\
\hline
\end{tabular}

presented average levels of $29.87 \mathrm{mg} / \mathrm{kg}$ (sd 3.14) in the eggshell, varying from 25.02 to $35.21 \mathrm{mg} / \mathrm{kg}$; $0.97 \mathrm{mg} / \mathrm{kg}$ (sd 0.26) in the yolk, ranging from 0.41 to $1.36 \mathrm{mg} / \mathrm{kg}$; and $0.57 \mathrm{mg} / \mathrm{kg}$ (sd 0.11 ) in the albumen, varying from 0.40 to $0.75 \mathrm{mg} / \mathrm{kg}$ (Figure 1). These values are considered higher than the environmental reference levels previously detected in Rio de Janeiro, Brazil, of 1,5mg. $\mathrm{m}^{3}$ of air (Quiterio et al., 2006). The main mode of lead contamination is possibly through the inhalation of fumes produced by lead smelting. The studied wild passerines species feed on fruits, nectar, and insects in the tree-crown environment (Manhães, 2003), which may be more protected from lead intoxication than ground-foraging species, unless the source of lead is present in the air as a vapor, as it might have happened in the neighborhood of the smelter. On the other hand, the fruits of the foraging trees might have also accumulated lead. In this episode, the distance may not be have had a role in the observed intoxication, in contrast with Levine et al. (1976), who detected geese mortality and clinical signs in cows at $300 \mathrm{~m}$ but not at $700-900 \mathrm{~m}$ from the smelter.

Lead contamination is a growing environmental concern (Projeto Geomed, 2008; Quiterio et al., 2006, Sanderson \& Bellrose, 1986). The dietary concentrations of lead acetate for fatal toxicity in chickens can be very high, from 320 (Damron et al., 1969) up to $1,000 \mathrm{mg} / \mathrm{kg}$ (Vengris \& Mare, 1974), allowing high levels of lead to be transferred to the chicken carcass and egg. Trampel et al. (2003) found levels of $0.02-0.40 \mathrm{mg} / \mathrm{kg}$ in the egg yolk and $0.45 \mathrm{mg} /$ $\mathrm{kg}$ in the eggshell of surviving lead-paint intoxicated chickens. On the other hand, our results were more than 66 times higher in chicken eggshells than those found by those authors, and more than 2.4 times the maximum value found in yolks.

The relevance of such findings may be considerable due to the possibility of high levels of lead being transferred to humans through chicken products. Lead intoxicated free-range chickens may maintain their egg production stable, as the chicken species is highly resistant to lead poisoning (Damron et al., 1969). For this reason, free-range chickens may function as longterm environmental sentinels, accumulating high levels of lead before developing clinical signs. The presence of mainly airborne lead in the area of study as fumes from smelting may also result in direct human contamination, as revealed by tests with workers and resident neighbors (unavailable data from the Municipal Department of Public Health).

\section{REFERENCES}

Brown TP, Julian RJ. Other toxins and poisons. In: Saif YM. et al. editors. Diseases of poultry. 11th ed. Ames: lowa State University; 2003.

Damron BL, Simpson CF, Harms RH. The effects of feeding various levels of lead on the performance of broilers. Poultry Science 1969; 48:1507.

De Francisco N, Ruiz Troya JD, Aguera El. Lead and lead toxicity in domestic and free living birds. Avian Pathology 2003; 32:3-13.

Levine RJ, Moore RM Jr., Mclaren GD, Barthel WF, Landrigan P. Occupational lead poisoning, animal deaths, and environmental contamination at a scrap smelter. American Journal of Public Health 1976; 66(6): 548-552.

Manhães, MA. Dieta de Traupíneos (Passeriformes, Emberizidae) no Parque Estadual do Ibitipoca, Minas Gerais, Brasil. Diet of Tanagers (Passeriformes, Emberizidae) in Ibitipoca State Park, Minas Gerais, Brazil. Iheringia, Série Zoologia 2003; 93(1): 59-73.

Pain DJ, Sears J, Newton I. Lead concentrations in birds of prey in Britain. Environmental Pollution 1994; 87:173-180.

Projeto Geomed. Paisagens geoquímicas e ambientais do Vale do Ribeira. São Paulo; 2008 [cited 2008 set 25]. Available from: http:/ /www.ige.unicamp.br/geomed/noticias_detail.php?registro $=25$

Quiterio SL, Moreira FR, Silva CRS, Arbilla G, Araújo UC, Mattos RCOC. Avaliação da poluição ambiental causada por particulado de chumbo emitido por uma reformadora de baterias na cidade do Rio de Janeiro, Brasil. Cadernos de Saúde Pública 2006; 22(9)

Sanderson GC, Bellrose, FC. A review of the problem of lead poisoning in waterfowl. Illinois: Natural History Survey; 1986. (Special publication, 4) [cited 2008 jul 28]. Available from: (http:// www.npwrc. usgs.gov/resource/birds/pbpoison/pbpoison.htm 
Martins NRS, Marques MVR, Vilela DAR, Resende JS, Carvalhaes AG, Andrade EAG, Barrios PR

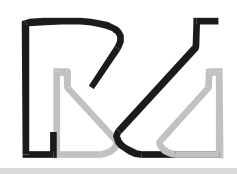

Lead Poisoning Mortality in Wild Passeriformes and its Detection in Free-Range Chicken Eggs in Southern Minas Gerais, Brazil

Trampel DW, Imerman PM, Carson TL, Kinker JA, Ensley SM. Lead contamination of chicken eggs and tissues from a small farm flock. Journal of Veterinary Diagnostic Investigation 2003; 15:418-422.

Vengris VE, Mare CJ. Lead poisoning in chickens and the effect of lead on interferon and antibody production. Canadian Journal of Comparative Medicine 1974; 38:328. 